\title{
EdUCATIONAL MANAgEMENT BASED ON LOCAL WiSDOM (DESCRIPTIVE ANALYTICAL STUdies OF CULTURE OF LOCAL Wisdom IN WEST KALIMANTAN)
}

\author{
Hamid Darmadi \\ Universitas Tanjungpura, Pontianak, Indonesia \\ E-mail: hamiddarmadi@gmail.com
}

\begin{abstract}
Education is a deliberate and planned deliberate effort to foster the development and potential of individual self-learners "learners" in order to benefit their life interests both as individuals and as members of the community. Education is one form of human culture because it must be seen as an activity that is always dynamic, following the acceleration of the rate of change and the dynamics of the culture of the community. Through education is expected to be organized the basis of values, thinking, and morality of the nation, in order to be able to produce a formidable generation in faith, personality, rich in intellectuality, and superior in the mastery of technology and information. For that, we need education based on local wisdom. The purpose of education based on local wisdom is in accordance with that has been stated in the Law. 20 Year 2003 About Sisdiknas Article 3, states that: "National education functions to develop the ability and form the character and civilization of a dignified nation in order to educate the nation's life". Local wisdom education is part of the culture of a society that can not be separated from the language of society itself. Local wisdom is passed down from generation to generation through word-of-mouth. Local wisdom is in folklore, proverbs, songs, and people's games. Local wisdom as a knowledge found by a particular local community through a collection of experiences in trying and integrated with an understanding of the culture and nature of a place. Along with the development of the age along with the rapid flow of information and technology are constantly changing, there is a tendency of local wisdom began marginalized. It needs to be socialized to the younger generation so that the culture of wisdom is not lost in time.
\end{abstract}

Keywords: Local Wisdom, Education, Management

\section{INTRODUCTION}

Education is a deliberate and planned deliberate effort to foster the development and potential of individual self-learners "learners" in order to benefit their life interests both as individuals and as members of the community. Education is one form of human culture, therefore education should be seen as an activity that is always dynamic, following the acceleration of the pace of change as well as the dynamics of the culture of society. This is reasonable considering that education should continue to adjust to the times, especially science and technology. But the dynamics and rate of change should not be uprooted from the roots of culture itself. Adjustment effort is realized in an effort to improve the quality of human resources as the predominant conditions required to enter the global era. It is directly related to the definition and mission of education. Through education is expected to regulate the basis of values, thinking, and morality of the nation, in order to be able to produce a strong generation in faith, solid in personality, rich in intellectuality, and excel in the mastery of technology and information. Which in turn is expected to play a role in contributing greatly to the enlightenment of families, Nusa, and nation.

With education, people can learn to give, learn to accept, learn to be patient, learn to appreciate, and learn to respect others, ethnic and religious differences. Through education, people can improve the quality of human resources (HR) it. One of the policies that can be developed to support the exclusion of quality human resources is "Management of Local Wisdom-Based Education". Improving themselves through the development of quality human resources is a natural thing, even a 
human nature as a creature that must be educated and get an education. However, the dynamics and the rate of change through or outside the educational context should not be uprooted from its own cultural roots, which in this paper is called "Management of Local Wisdom-Based Education". Business Management of Cultural Education Based on Local Wisdom "is implemented in the form of efforts to improve the quality of human resources as the predominant conditions required to enter the global era.

Implementation of cultural education management based on the local wisdom of the $21 \mathrm{st}$ century should be able to be a milestone in the formation of a superior civilization capable of presenting human as mentioned in the Vision of Mission management education based on local wisdom culture; "Forming a competitive champion generation, deductive and noble character. The champions of the champions are aimed at the order of the mindset that is the creation of a formidable, unyielding, courageous, optimistic, sportive, honest, and desperate generation who possess competitive spirit (deductive quality) deductive and noble moral, civilized and cultured). While the mission pursued is to carry out the concept of education based on the Law No. 20 of 2003 on National Education System reads: "National education functions to develop the ability and form the character and civilization of a dignified nation in order to educate the nation's life, aims for the development of potential learners to be human beings who believe and cautious to God Almighty, have a noble character, healthy, knowledgeable, capable, creative, independent, and become citizens of a democratic and responsible.

Controlling Back on the basis of education based on local wisdom that is education from society, by society and for society, in the process of organizing education control done jointly between the board, manager, and society. All elements are responsible for controlling the course of education. This joint control is a testament to the seriousness of all parties, especially educational managers, in order to produce cultured people. At the level of implementation of local wisdom-based culture management education, the community must participate in controlling and supervising the decision-making process that concerns the utilization and management of education. That way, education does not only take place in a small classroom but can occur in every space and time.

The complexity of problematic education in Indonesia today, in the form of powerlessness in building a graceful and enlightened national identity, in the form of the inability to reconstruct the potential of the nation in a responsive and dynamic. The problematic that leads to the intrinsic problems and extrinsic problems of education in this country. Intrinsic issues concerning curriculum, methodology, education personnel, and educational instruments, as well as extrinsic problems with regard to the impact of globalization, political, socio-economic, demographic, and so on. It requires a concrete comprehensive answer in building the education system with paradigm and educational orientation as a cultural strategy that brings value supremacy and education to the technical pragmatic aspect. In this case, it is necessary to develop the management of culture-based education to the local wisdom.

Local wisdom is part of the culture of a society that can not be separated from the language of society itself. Local wisdom is usually passed down from generation to generation through word-ofmouth. Local wisdom is in folklore, proverbs, songs, and people's games. Local wisdom as a knowledge found by certain local communities through a collection of experiences in trying and integrated with an understanding of the culture and state of nature of a place (Padmanugraha, 2010: 12).

Each region in Indonesia has the advantage of potential areas that need to be developed better. The advantages possessed by each region vary greatly. With the diversity of potential of this region need to get special attention for the local government so that learners are familiar with their own local area and understand well about the potential and the values and culture of their own region in accordance with the guidance of the global education era.

In the midst of the vortex of global hegemony, the phenomenon that occurred also has made educational institutions seemed to lose space. It also makes the depth of understanding of learners about local history and cultural traditions that exist in the community in the region. Therefore it would be better if attempted how to make a variety of cultures owned by this nation can be maintained and preserved together. With local-based education management then we can be optimistic that the creation of education that can give meaning to the human life in Indonesia. This means that education will then be able to become a spirit capable of coloring the dynamics of Indonesian man today and the future.

Our national education should be able to form a human with high integrity and character to Indonesian so as to bear the children of a great nation and dignified in accordance with the spirit of $21 \mathrm{st}$ century education that is; Today's education is not only to produce good citizens but to focus on global citizens who have the skills, knowledge, and motivation to deal with humanitarian and environmental issues. In this context, in particular, the 21st Century Learning (PA21) in cultural diversity is to create a mixture of various peoples and ethnicities in order to eliminate the prejudices and stereotypes of people in an effort to foster positive attitudes and arouse respect for ethnic, national, cultural differences. The value of different cultures should be understood as a set of values that go hand 
in hand with the social system of community of the nation.

In the 21st Century Education Implementation Guidelines (2017), there are several critical capabilities that should be mastered in PA21 that, as noted by American scholars, states four (4) the most important special abilities: Creativity, Communication, Collaboration, and Critical (4). In line with that James (2017) mentions this occurrence there is also an attempt to add $2 \mathrm{C}$ in PA21 namely citizenship and character. In addition, the guidance also refers to Model Osler and Starkey (2005) which explains in the aspect of citizenship a learner should know the respective roles of a citizen regarding status, rights, practice, and competence. Whereas in the aspect of the development of the character also, PA21 is expected to have the ability and skill to lead and collaborate with others. 21st Century Education in Cultural Diversity: Chart and Hope (PDF Free Download). Available from: https: // www. researchgate. net / publication / 320858903.Pendidikan_Abad_ke_21 In Cultural Variety Cabaran_dan_Harapan [accessed 24 May 2018].

If we see from the understanding, the local wisdom is a human policy in developing local excellence that relies on the philosophy of values, ethics, ways and behaviors that are traditionally institutionalized. Local wisdom can be understood as local ideas that are wise, full of wisdom and good value embedded in society and followed by the community. Local wisdom is a conceptual idea that exists in people's lives and grows and continues to grow in a community awareness that serves to regulate the life of the community. Local wisdom usually develops in the community through oral traditions such as tembang macatat which is found in Java. The hallmark of local wisdom alone is being able to withstand foreign cultures or new cultures and have the ability to accommodate foreign cultural elements.

\section{Methodology}

This research uses descriptive method with qualitative research form. Data analysis In this research used descriptive qualitative analysis method. Qualitative descriptive data analysis is a method that describes qualitatively the facts, data, objects, materials in the form of expression, discourse through appropriate interpretation and systematic (Wibowo, 2014) Problem solving focussed for: Management of Local Wisdom-Based Education Analytical analysis qualitative perspective by interpreting data and facts found in theoreticalpractical research.

The data collected in this study consist of primary data and secondary data. Primary data is obtained directly through field studies, while secondary data is obtained through literature, literature and from customary figures, indigenous figures of data sources and information that can be accounted for its scientific validity. The data were collected by using data collecting technique in the form of discussion, documentation study, and literature, data analysis was done descriptively qualitative by tabulating the data obtained in accordance with the purpose of research.

\section{RESULTS AND DISCUSSION}

\section{A. Developing Local Wisdom-Based Education}

The wisdom of local wisdom (local genius) can basically be seen as the foundation for national identity formation. Local wisdom is what makes a nation's culture has its roots. Local ethnic cultures often serve as a source or reference to new creations, for example in language, art, community order, technology, and so on, which are then featured in cross-cultural life. The motivation to explore local wisdom as a central issue, in general, is to seek and ultimately, if desired, to establish the identity of the nation, which may be lost by the process of dialectical crosses or by acculturation and transformation that has been, is, and will continue to occur as inevitable. For us, the effort to find a new national identity based on local wisdom is important for the unity of the nation's culture on the basis of the identity of the archipelago regions.

The development of relevant and contextual local wisdom has significance for the development of a nation, especially when viewed from the point of cultural endurance, as well as having significance for the identity of the region itself. Development of local wisdom of a region will encourage a sense of pride in the culture and also proud of its area because it has participated in contributing to the development of the nation's culture. The cultural artworks, excavated and local sources, if presented in a 'face or discourse of Indonesianness' would undoubtedly have a tremendous contribution to the creation of a whole new identity for the nation as a whole.

Local wisdom can be used as a bridge connecting past and present, generations of ancestors and present generations, to prepare for the future and future generations. In turn, local wisdom can be used as a kind of adhesive node and unify the intergeneration. It, therefore, becomes an urgent imperative to continue to explore and 'protect' the local wisdom found in every local ethnic through possible efforts, including through any cultural "education" (culture) of any form of education: formal- informal. By always taking into account local wisdom through and in cultural education undoubtedly human beings are not caught in a situation where a man is alienated from his reality in the sense of "becoming like (others)." Thus, local content in cultural education should always be 
interpreted in the context of liberation in order to be more acquainted with ourselves and the environment, rather than as sociocultural domestication. Economically advanced and technologically advanced western culture has inevitably struck us so strongly that we feel the loss of (some) of the traditional identity of the nation The emergence of a desire to rebuild the identity of the nation can, in essence, be considered as an important means of selecting, rather than resisting, the influence of other "cultures." Digging and reinventing local wisdom inherently through education can be said to be a return movement on the basis of the cultural values of its own region as part of efforts to build a nation's identity, and, as a kind of filter in selecting "other" cultural influences. The values of local wisdom necessitate a strategic function for the formation of character and identity of the nation. Education that cares about it will lead to the emergence of an independent, initiative, and creative attitude. Finally, if the cultural values are successfully implanted through education that serves the nation's intellect, will also produce human beings who are efficient in life and able to also live their local wisdom and have a strong identity which in the end will be able to have cultural value national transethnic in the future. Now just how the role of government in realizing it.

The identity of the nation is one form of development of the character of the nation, identity has the meaning of a nature, character, reason, taste, intention, the will, the spirit contained in human soul as a result of the process of learning about the broad and emerging cultural values in behavior or action. So the self of the nation, especially Indonesia has a characteristic that is certainly able to distinguish it from other nations. But as the social change of the original national identity that gradually began to fade. A typical identity that Indonesia has for many years, among others, religious, humanist, naturalist, open, democratic, nationalist, patriotic, juju and fair, professional, spirited culture, artistic, and so on. But along with the development of peculiarities is increasingly faded. The way to overcome the waning of the national identity, among others, by strengthening the ideology and nationalism through various activities such as flag ceremonies, the development of science and technology with faith, preventing the spread of drugs, alcohol and love, loving the product in the country, and the last by maintaining the sustainability and continuity of value as well as norms in the community starting from an early age through cultural education based on local wisdom.

When modernism sneaks into the trunk of the Indonesian nation, the trap that leads to the neglect of original cultural originality is inevitable. The information-technology stream has destroyed the cultural milestones. The big wave of information technology is not just crossing cultural boundaries, it can ruin the national identity. Human identity as part of a community group is no longer the power to be preserved from its characteristics. The changes that have resulted in the change of mind and character are the impact of cultural change. Globalization has taken place in various fields, including in science and technology, socio-political, cultural, and ethical, which have implications for the many problems that arise in education in various countries. The new world that today's civilization offers only succeeds in teaching pragmatism, the practical life-longness (Naufal, et al., 2014; Idi, 2014; Rif'an, et al., 2012).

\section{B. Local Wisdom of Dayak Tribe Against Nature}

Long before the advent of conservation and the protection of modern nature, Dayak tribes have been practicing from generation to generation, what is the essence of the concept of conservation by preserving forests in their neighborhoods. Dayak human nature that is characterized by socio-religious magic, in turn, gave birth to religious attitudes and behavior in the form of forest resource management practices in a wise and responsible. Implementation of conservation and protection of nature by the Dayak people can be traced through the use of various terminologies such as Tajahan, Kaleka, Sapan Pahewan, Support of Himba and others. The meaning of terminology and its relevance to modern conservation efforts and efforts are outlined as follows:

1. Headline

Tajahan is a place that is sacred by Dayak tribe especially Kaharingan. At the location of the colony erected a small house to place the offering as a sacrifice for the spirits who dwell in that place. The small house is generally equipped with small statues as symbols or replicas of deceased family members whose spirits are believed to dwell in these small statues and will not disturb the surviving family members. The location of the colony is generally located in the jungle area is still thick and impressed haunted. In the area that is the location of the landmark, there is a prohibition to perform various human activities such as cutting down trees, picking up forest products, hunting, and other activities. Enforcement of activity restrictions at this location is highly relevant to the concept of conservation because it contains aspects of forest protection and biodiversity, as well as the conservation of nature and the awakening of the conservation of the nature reserve.

\section{Kaleka}

Kaleka is a site of ancestral relics of Dayak tribe since ancient times are generally marked by the rest of the pole buildings betang/rumah panggung, big old trees like durian, langsat and so forth. The location is usually always maintained and protected by the family for generations as a heritage that the designation and utilization solely for the common good. From the perspective of ecological 
conservation, Kaleka is the "granary" of the Dayak Plasma Nuftah.

3. Sepan Pahewan

Sepan Pahewan is the location of the saltwater source which is a place for forest animals such as deer, deer, mouse deer and other bananas drink salt water as a mineral source. The location of Sepan Pahewan is a hunting ground for the Dayak tribe to meet animal needs so that the location is always maintained and protected. The local wisdom of the Dayak tribe by protecting and maintaining the location of Sepan Pahewan is very relevant to the conception of animal protection in today's nature conservation.

\section{Support the Himba}

The support of Himba is part of the forest area which is functioned as a place to move the spirits (Ganan Himba in Dayak Ngaju language) from the location that will be used as a place of farming, therefore the location of Pukung Himba is purposely not felled and left as a reservation area. The Dayak tribesmen in Kalimantan generally understand very well that in the opening act of the field, it must provide the location of Pukung Himba that is the reserved forest area as a place for the forest waiting for spirits that are removed from the location to be used as fields. Signs of the area used as Supporters of Himba are usually heavily forested, there are old trees with large diameter wood vegetation, not much touched by human activity and many inhabited by wildlife. An old forest with a large wooden size and impressive so haunted is believed to be the preferred place for the forest guard spirits to settle.

The existence and concept of Himba Support are viewed from the perspective of conservation is the effort of conserving the forest area along with the biodiversity in it. The philosophy of harmonizing the Dayak tribe with nature, with God the Creator, and with fellow human beings has been established and reflected in the implementation of ecological wisdom Tajahan, Kaleka, Sapan Pahewan, Support the himba and others. That is the Local Wisdom of the Dayak Tribe Against Nature by practicing customs and traditions as earth service, and maintaining the existing ecological balance.

\section{The Importance of Local Wisdom Management Education}

Local wisdom is seen from the English dictionary of Indonesia, consisting of 2 words of wisdom (wisdom) and local (local). Local means local and wisdom same with wisdom. In other words, local wisdom can be understood as a wise, wise, good-value local ideas, values, embedded and followed by members of the community. The local term specifically refers to a limited interaction space with a limited value system. As an interaction space that has been designed in such a way that in it involves a pattern of relationship between humans with humans or humans with their physical environment. The pattern of interaction that has been designed is called setting.

Local wisdom or often called local wisdom can be understood human effort can be understood as a human effort by using the sense of his (cognition) to act and behave towards something, objects, or events that occur in a certain space. The definition is arranged etymologically, in which wisdom is understood as a person's ability to use his or her reason in acting or act as a result of an assessment of an object or event that occurs. As a term wisdom is often defined as wisdom or wisdom (Ridwan, 2007: 2-3).

Local wisdom is a form of dialectic between human and life knowledge. Knowledge derived from the life in which the human being is then reflected to help humans make sense of life. As a guideline for the community, then local wisdom provides a clear guidance of domains that can be reached by human behavior. In the process of formation, local wisdom is not conceptualized individually but requires a communal role of the community. Furthermore, local wisdom becomes part of the culture to become the identity and even the character of a society. Therefore, between local wisdom and culture is the relationship between the child and the parent. Local wisdom is nothing but a part of the culture itself.

Koentjaraningrat (1984: 8-25) says that cultural value is an abstract layer and its scope is wide. These levels are ideas that conceive of the most valuable things in people's lives. A system of cultural values consists of conceptions that live in the minds of most citizens about the things they should consider as valuable in life. Therefore, a cultural value system usually serves as the ultimate guide to human behavior. Other systems of human behavior that are more concrete, such as special rules, laws, and norms, all are also guided by the cultural values. cultural values that can encourage development, including the nature of endurance suffering, trying hard, tolerant of the establishment or trust of others, and mutual cooperation.

Local wisdom seen from the English dictionary of Indonesia consists of two words of wisdom (wisdom) and local (local). Local means local and wisdom same with wisdom. In other words, local wisdom can be understood as the ideas, values, views (local) wise, full of wisdom, good value, embedded and followed by members of the community. Local wisdom-based education is education which teaches learners to always be attached to the concrete situation they face. Paulo Freire (Wagiran, 2010) mentions, faced with concrete problems and situations encountered, learners will be more challenged to respond critically. This is in line with the opinion of Suwito who expressed the pillars of local wisdom education include: 
1. Building educated human beings must be based on the recognition of human existence since in the womb,

2. Education must be based on truth and virtue, distancing themselves from improper thinking,

3. Education must develop a moral, spiritual (affective sphere) area rather than a cognitive and psychomotor domain, and

4. Cultural synergy, education, and tourism need to be developed synergistically in character education (2008).

Local wisdom is the capital of noble character formation. Noble character is the character of a nation that always acts with full consciousness, selfancient, and self-control. The incandescent of local wisdom always swirls on the effort to abandon the passions, minimize the desire, and adjust with the board empan. Local wisdom is a discourse of the greatness of the moral order. Efforts to develop the education of local wisdom will not be implemented properly without optimal community participation. Participation of various elements in the community in taking initiative and becoming an educational program provider is an invaluable contribution, which needs attention and appreciation. Various forms of local wisdom that is the carrying capacity for the implementation and development of education in society, among others, as follows.

1. Local community wisdom in the form of written regulations on learning obligations, such as the obligation to follow the learning activities for people who are still illiterate.

2. Local wisdom in maintaining the harmony of relationships between people, through mutual community-supported activities in various activities.

3. Local wisdom related to art. Certain piety has value to awaken a sense of togetherness and exertion and a sense of respect for leaders and "aged" people,

4. Local wisdom in the recommended system (unwritten), but agreed in the meeting attended by elements in indigenous peoples to realize the intelligence of citizens, such as the obligation of citizens to know read and write when taking care of Identity Card and Family Card.

Local wisdom in foreign languages is often conceptualized as local policy, local knowledge or local intelligence. Local wisdom can also be interpreted as a thought about life. The thought is based on clear reason, good mind, and load positive things. Local wisdom can be translated as the work of reason, deep feeling, character, form of temperament, and the suggestion for human glory. Mastery over local wisdom will bring their souls more virtuous. Naritoom (Wagiran, 2010) defines local wisdom with the following definition: "Local wisdom is the knowledge that discovered by the people through the accumulation of experiences in trials and integrated with the understanding of nature and culture. Local wisdom is dynamic by the function of created local wisdom and is connected to the global situation ".

The definition of local wisdom, at least implies some concepts, namely: (1) local wisdom is a long experience, which is precipitated as a guidance of one's behavior, (2) local wisdom cannot be separated from the owner's environment, and (3) local wisdom is dynamic, flexible, open, and constantly adjust to the times. Such a concept also at the same time gives an idea that local wisdom is always related to human life and environment. Local wisdom emerges as a global climate watch or filter that plagues human life. Wisdom is a process as well as a product of human culture, used to survive. This notion, similar to Geertz's (1973) idea: "Local wisdom is part of culture. Local wisdom is a traditional culture element that is related to human resources, source of culture, economic, security and laws. local wisdom can be viewed as a tradition that related to farming activities, livestock, build house etc ".

Local wisdom is part of the culture. Dayak local wisdom is part of the Dayak culture, which has a particular view of life. Various things about human life will emit hundreds and even thousands of local wisdom. Furthermore, there are some characteristics of local wisdom, among others: (1) local wisdom appears to be simple, but often is elaborate, comprehensive, diverse, (2) It is adapted to local, cultural, and environmental conditions, (3) It is dynamic and flexible, (4) It copes well with changes.

Based on the above understanding, it can be mentioned that local wisdom is a contextual culture. Wisdom always comes from human life. As life changes, local wisdom will change as well.

\section{Basic Law of Local Kearipan Education}

The basis of local wisdom-based education originated from a phrase conveyed by Jhon Naisbit (1990) which was then responded and developed by some social experts with the expression of thinks globally acts locally (think global and act locally). The purpose of the phrase is that one can take on any experience and knowledge, from any tribe or nation, but in its application in action when one is in a place, it must conform to the values and culture that exist in that place. Basic education based on local wisdom is presented among them as follows:

1. The 1945 Constitution of the Republic of Indonesia Article 18 B Paragraph (2) of the 1945 Constitution of the State of the Republic of Indonesia that "the State recognizes and respects the units of indigenous and tribal peoples as long as they are alive and in accordance with the development of society and the principle of the Unitary State of the Republic of Indonesia, regulated in the law ", is also affirmed in Article 28 I Paragraph (3) of the 1945 Constitution of the Republic of Indonesia which states that" The 
cultural identity and rights of traditional societies are respected in harmony with the development of the times and civilizations. "

2. Law No. 5/1960 on Agrarian Principles Article 3 provides that the exercise of customary rights and similar rights from indigenous and tribal peoples, insofar as they still exist, shall be such that in accordance with national and state, based on the unity of the nation and should not conflict with other laws and regulations.

3. Law No. 5 of 1990 on the Conservation of Biological Natural Resources and its Ecosystems. In this law, the role of government is enormous, in the activities of conservation of natural resources and ecosystems. With the size of the government's role, space for indigenous and tribal peoples to conserve natural resources is almost nonexistent. This law does not mention any of the regulations on indigenous and tribal peoples, although customary law communities in various places have the institutions, knowledge, and experience of natural resource conservation.

4. Act No. 39 of 1999 on Human Rights This Law expressly states in Article 6 paragraph (1) that: "In the context of human rights enforcement, the differences and needs of indigenous and tribal peoples shall be observed and protected by law, society, and government. "

5. Law Number 32 Year 2004 regarding Regional Government Article 2 paragraph (9) of this law affirms that the state recognizes and respects the unity of indigenous and tribal peoples along with their traditional rights as long as they are alive and in accordance with the development of society and the principle of the Unitary State of the Republic of Indonesia.

Given the global knowledge, one can easily read and recognize a problem and solve it. Therefore one needs to be knowledgeable so that insight becomes relatively broad. However, in terms of education in general and learning to teach in particular, an educator is not enough just with knowledgeable and broad-minded, but to reflect the transfer of knowledge (learning process) must also be accompanied by emotion skill (emotional ability) is how an educator can enter into the world is located.

In local communities, within a single local community, it will be different from other local communities. That is why in Indonesia there is a motto 'Bhinneka Tunggal Ika' which means that although we come from different tribes and different cultures, we have one unity that is Indonesia. From the word slogan mentioned above can be concluded that the Indonesian state indeed has much local wisdom of people who have different cultural diversity as well. Therefore, it is certain that the Indonesian state actually has a cultural richness that can give a color that can be developed into a character of the nation.
Education based on local wisdom is actually a form of reflection and realization of the Government Regulation Number 19 Year 2005 on National Education Standards, namely article 17 paragraph 1 which explains that the curriculum level of elementary-secondary education, or other similar forms developed in accordance with the educational unit, the potential regional, socio-cultural, and learners.

Local wisdom or local wisdom means local wisdom. In general understanding of Local Wisdom is the ideas, values or views of a place that has wisdom and good value followed and trusted by people in a place that has been followed for generations.

Local Wisdom is characterized by several other things as follows:

1. Have the ability to control.

2. It is a stronghold to survive from outside cultural influences.

3. Have the ability to accommodate outside cultures.

4. Have the ability to give direction to the development of culture.

5. Have the ability to integrate or integrate the outside culture and native culture.

Local Wisdom is an explicit knowledge that arises from a long period and evolves with the community and the environment in its region based on what has been experienced. It can be said that the local wisdom in each region varies depending on the environment and the necessities of life in that area.

E. Characteristics of Local Wisdom in the World of Education

There are a number of proven traditional or ethnocentric practice education practices. Call it cultural praxis in traditional villages such as Kampung Naga and Baduy are praised in preserving the environment. Likewise, the boarding education system in traditional pesantren has produced graduates who have a strong and entirely entrepreneurial spirit that is almost unheard of to aspire to become a civil servant. That is the right local wisdom to be the basis of education and culture. Etnopedagogi is a practice of education based on local wisdom in various domains such as medicine, martial arts, environment, agriculture, economy, government, dating system, and so on. From there it will develop ethnophilosophical, ethnopsychological, ethnomusicological, ethnopolitical, and the like.

Etnopedagogi views local knowledge or local wisdom as a source of innovation and skills that can be empowered for the welfare of society. Local wisdom is a collection of facts, concepts, beliefs, and public perceptions about the world around. This includes how to observe and measure the environment, solve problems, and validate information. In short, local wisdom is the process by which knowledge is generated, stored, applied, 
managed, and inherited. There are several characteristics of local wisdom: (1) based on experience (2) tested after centuries use (3) can be adapted to the present culture (4) united in the daily practice of society and institution (5) commonly done by individuals or society as a whole (6) are dynamic and constantly changing (7) strongly related to the belief system. Empowerment through the adaptation of this local knowledge, including the reinterpretation of the values contained in a number of proverbs, with contemporary conditions is an intelligent strategy for solving social problems because in many cases social problems are sourced on local issues as well. There needs to be a synergy between local government and cultural warriors, as well as universities to develop academic concepts and to pilot ethnocentric and pedagogic models. Until now, for example, there has been no research on the impact of the use of Sundanese as the medium of instruction in schools, classes, or certain subjects. It should not be forgotten that the revitalization of local wisdom in ethnopedagogi is not sufficiently done personally, but must be done in an institutional and cross-sectoral congregation.

\section{F. Scope of Local Wisdom}

Local wisdom is a broad and comprehensive phenomenon. The scope of local wisdom is quite wide and varied, making it difficult to be limited by space. Traditional wisdom and wisdom now differ from local wisdom. Local wisdom puts more emphasis on the place and locality of the wisdom so it does not have to be a wisdom that has been passed down from generation to generation.

Local wisdom can be a wisdom that has recently emerged within a community as a result of its interaction with the natural environment and its interaction with other communities and cultures. Therefore, local wisdom is not always traditional because it can include today's wisdom, and therefore it can be broader in meaning than traditional wisdom. To distinguish local wisdom that has just emerged with local wisdom that has long been known to the community can be used the term wisdom now, new wisdom, or contemporary wisdom. Traditional wisdom can be called old wisdom or old wisdom. Based on the time of appearance mentioned above, there will be wisdom in various categories. At least, there are two types of local wisdom: (a) classical, old, traditional, and (b) local, contemporary local wisdom. This kind of category covers a variety of things and is very fluid in shape. That is, the old and new terms are often fluid.

In terms of basic philosophy, wisdom can be categorized in two aspects: (a) ideas, thoughts, abstract minds, and (b) local wisdom in the form of concrete things can be seen. The local wisdom of the category (a) includes the knowledge, views, values and practices of a community both derived from the previous generation of the community as well as those acquired by the community today, which did not originate from the previous generation but from various experiences in the present, as well as from its contacts with other communities or cultures. Local wisdom categories (b) are usually objects of artifacts, which adorn human life, and are symbolic for a nation's people.

In Indonesia, local wisdom clearly has a positive meaning because wisdom is always interpreted in a good or positive. The selection of local wisdom words is recognized or not is a strategy to build, create a better image of local knowledge, which is not always interpreted positively. By using the term local wisdom, consciously or not people are willing to appreciate traditional knowledge, local knowledge of ancestral heritage and then willingly bother to understand it to be able to obtain various wisdom that exists in a community, which may be relevant to human life in the present and in the future will come.

In every span of human life, there is always local wisdom. At the very least, wisdom can arise in: (a) thought, (b) attitude, and (c) behavior. All three are almost difficult to separate. If all three are lame, then the local wisdom is increasingly faded. In thought, there is often noble character, virtuous, but if mobah mosik, solah take, not good also considered not wise, especially if its action is not praiseworthy. Broadly speaking, local wisdom consists of things that are not visible (intangible) and tangible things (tangible). The invisible wisdom is a noble idea of self-development, preparing for a wiser life, and noble character. Conversely, wisdom in the form of physical and symbolic things should be reinterpreted in order to be easily implemented into life.

Viewed from its type, local wisdom can be classified into five categories, namely food, medicine, production techniques, home industries, and clothing. This classification is certainly not appropriate because there are many other things that may be far more important. Therefore, local wisdom cannot be restricted or segregated. Sungri (Wagiran, 2010) categorization includes agriculture, handicrafts, herbal remedies, natural resource and environmental management, trade, cultural arts, regional languages, philosophy, religion, and culture as well as traditional foods.

Suardiman (Wagiran, 2010) reveals that local wisdom is identical with human behavior related to (1) God, (2) natural signs, (3) environment/agriculture, (4) building houses, (5) education, 6) marriage and birth ceremony, (7) food, (8) human life cycle and character, (9) health, (10) natural disaster. The scope of local wisdom can also be divided into eight, namely: (1) locally developed norms, such as Javanese behavior, taboos and obligations, (2) rituals and traditions of society and the meanings of the opposite, (3) folk songs, , myths and folklore that usually contain lessons or specific 
messages only recognizable by local communities, (4) data and knowledge information gathered on the elders of the community, indigenous elders, spiritual leaders, (5) manuscripts or scriptures (6) the ways in which local communities fulfill their daily lives, (7) the tools used for particular needs, and (8) the natural resource / environmental conditions commonly used in the livelihood of the day-to- day.

In the cultural sphere, the physical dimensions of local wisdom include: (1) traditional ceremonies, (2) cultural preservation, (3) tourism, (4) traditional transportation, (5) traditional games, (6) cultural infrastructure, (7) (11) cultural arts, (13) arts and crafts, (14) folklore, (15) children's clothing, and (16) puppets. Other sources of local wisdom can be a Javanese life cycle that includes: tingkeban ceremony, birth ceremony, circumcision, marriage, and death. Local wisdom can be extracted from a particular area. Within the scope of Java, for example, the study of local wisdom can be studied from the philosophy of Javanese palace culture values which include: spatial, building architecture, vegetation symbol, symbol and meaning of ceremony and regalia, dispute, government, powerful concept, and leadership. From a cultural perspective, it can be comprehensively observed from the Javanese cultural values which include aspects of (1) religio-spiritual, (2) moral, (3) community, (4) customs and traditions, (5) education and knowledge, (6) ), (7) spatial planning and architecture, (8) livelihood, (9) arts, (10) language, (11) cultural heritage and cultural heritage area, (12) leadership and government, (13) nationality, and (14) the spirit of kejawaan. These fourteen aspects can further be elaborated in detail into the points of value. Various kinds of local wisdom is a potential development of education based on local wisdom. That is why, the world of education needs to immediately design, determining the most appropriate model to do the seeding of local wisdom. Local wisdom can be a humanist character education medium.

\section{G. Objectives and Benefits of Local Wisdom-Based Education}

The purpose of local wisdom-based education is in accordance with the Law No. 20 of 2003 on National Education System Article 3, states that national education functions to develop the ability and form the character and civilization of a dignified nation in order to educate the nation's life. National education aims to develop the potential of learners to become human beings who are faithful and devoted to God Almighty, have a noble character, healthy, knowledgeable, capable, creative, independent, and become citizens of democratic and responsible. While benefits of education-based (b) reflect on cultural values, (c) participate in shaping the character of the nation, (d) contribute to the creation of national identity, and ( e) take part in preserving the nation's culture.

\section{H. Local Wisdom As A Value}

Talking about values, then, of course, cannot escape from a word of integrity, which when discussed further, then the integrity will become an identity. In this case, there is a study conducted at Harvard University of the United States (Ali, 2000), which states that the success of a person cannot be determined solely because of the influence of knowledge and technical skills (hard skills), but rather because of the ability managing themselves and others (soft skills). The study revealed that success is only about 20 percent determined by hard skills and the remaining 80 percent is determined by soft skills.

Local culture-based learning is the creation of learning environments and the design of learning experiences that integrate local culture as part of the learning process. Learning based on local culture, culture is integrated as a tool for the learning process to motivate students in applying knowledge. Suastra (2005) says that the values held by indigenous people are full of wisdom values (local genius). Sutarno (2007) said that cultural-based learning can be divided into four kinds, namely learning about culture, learning with culture, learning through culture, learning culture.

Cultures are studied in special courses, on culture, and for culture. Learning with culture occurs when culture is introduced to students as a way or method for learning certain subjects. Learning with culture involves the use of different forms of cultural manifestation. Learning with culture, is the culture and its embodiment into learning media in the learning process, into the context of examples of concepts or principles in a subject, and into the context of application of principles or procedures in a subject. Learning through culture is a strategy that gives students the opportunity to demonstrate the attainment of understanding or meaning it creates in a subject through a variety of cultural manifestations. Learning culture is a form of cultural embodiment in the actual behavior of students daily.

The use of local culture (ethnic) in Cultural Based Learning is very beneficial for the meaning of process and learning outcomes because learners get a contextual learning experience (goat sheets) and apperception materials to understand the concept of science in local culture (ethnic) owned. In addition, the cultural integration model in learning can enrich the local culture (ethnic) which in turn can also develop and strengthen the national culture which is the culmination of local culture and the growing ethnic culture (Dikti, 2004: 4). According to Sutarno, in cultural-based learning, culture is integrated as a tool for the learning process to motivate learners in applying knowledge, working cooperatively, and perceiving the interrelationship between the various subjects. 
The way that educators can do, whether teachers or learners, is by exploring the potential value shared in a local community. From there then a principal of education will be able to make changes to the world of education undertaken and occupied by them. It corresponds to a term derived from one of Moroccan intellectuals, Muhammad Abed Al-Jabiri who says "Attajdidu mina dhdhahl" change must depart from our tradition, meaning that change is not by borrowing the traditions of people or other nations.

I. Local Wisdom Resources

1. Viewed from Human Potential

Al-Ghazali calls human potential there are four components, namely: spirit, heart, mind, and lust. Sigmund Freud shares components of the human personality system including superego, ego, and id. While Bloom divides the structure of human personality into three components, namely cognitive, affective and psychomotor. Howard Gardner translates into eight types of intelligence, namely: linguistic, logical-mathematical, spatial, physical kinesthetic, musical, interpersonal, intrapersonal and naturalist. The development of educational programs that include objectives, curriculum, learning methods and the educational environment should be based on the human potential of the students.

\section{Viewed from the Potential of Religion}

There is hardly any education in any part of the world that is free from religious influence, be it formal education or non-formal education. The dark world of education on ethical moral values and the life of a nation filled with greed and hypocrisy have the need to strengthen the values of Sufism, not only through religious education but also all the subjects, model, and school culture. Schools, colleges, and Islamic boarding school are not only the last moral guard castles but are also expected to give birth to wise and moral people.

\section{Viewed from Cultural Potential}

Culture is the value, process, and outcome of human inventiveness, tastes, and intentions. Culture or national culture has a very important position in the national education development program of a nation or local content of a region. A cultured nation and a great nation is a nation that respects, develops and passes on its culture to the younger generation. Through the richness of culture, we should be able to arrange various models and programs of education and learning can be in the form of study program, intracurricular, extracurricular or in the form of school culture.

4. Viewed from the Natural Potential

Through environmentally-based educationbased programs, it is expected to grow local wisdom and environmentally-caring character and vice versa can exploit the potential of its environment. A wise person is a person who lives in harmony with the environment while he can take advantage of the environment for the benefit of his life and the character will be angry if the ecosystem environment is damaged.

\section{J. Local Wisdom In Education}

There are a number of proven traditional or ethnocentric practice education practices. Call it cultural praxis in traditional villages such as Kampung Naga and Baduy are praised in preserving the environment. Similarly, the boarding education system in various forms of educators. Some of the characteristics of local wisdom include: (1) based on experience (2) tested after centuries use (3) can be adapted to the present culture (4) united in the daily practice of society and institution (5) commonly done by individuals or society as a whole (6) are dynamic and constantly changing (7) strongly related to the belief system. Empowerment through the adaptation of this local knowledge, including the reinterpretation of the values contained in a number of proverbs, with contemporary conditions is an intelligent strategy for solving social problems because in many cases social problems are sourced on the issue of local wisdom.

Etnopedagogi is a practice of education based on local wisdom in various domains such as medicine, martial arts, environment, agriculture, economy, government, dating system, and so on. From there it will develop ethnophilosophical, ethnopsychological, ethnomusicological, ethnopolitical, and the like. Etnopedagogi views local knowledge or local wisdom as a source of innovation and skills that can be empowered for the welfare of society. Local wisdom is a collection of facts, concepts, beliefs, and public perceptions about the world around. This includes how to observe and measure the environment, solve problems, and validate information. In short, local wisdom is the process by which knowledge is generated, stored, applied, managed, and inherited.

\section{CONCLUSION}

To establish national identity through education can be done by restoring learning to local wisdom. The characteristics of local wisdom are: (1) based on experience (2) tested after the use of centuries (3) can be adapted to the present culture (4) united in the daily practice of society and institution (5) commonly done by individuals or society as a whole (6) are dynamic and constantly changing (7) strongly related to the belief system. Building an education system means a planned effort in the form of optimization of educational components. There are three pillars in building Indonesia's education system area. Reorientation and curriculum reform $b$. Teacher quality improvement c. Selection Prospective Trauma Selection Mechanism. Strengthening of national character can be started from the optimization of character education based on local wisdom through learning. Contextual and contextual learning can 
contribute to capturing local wisdom issues in culture. The appointment of local wisdom needs to be accommodated. Especially if you see the literature of a multicultural region like Indonesia should be excavated again. Local wisdom cultural - based learning is highly relevant to apply.

\section{REFERENCES}

Alue Dohong. "Kearifan Lokal Dayak dalam Perlindungan Flora dan Fauna Endemik." Sustainability-of-Central Kalimantan. 24 Mei 2009. Diakses 25 April 25

2016. http://aluedohong.blogspot.co.id/2009/0 5/kearifan-lokal-dayak-dalamperlindungan.html

Alwasilah, A. Chaidar, 2006, Tujuh ayat etnopedagogi, htt://beta.pikran-rakyat.com, 21 Juli 2006 azwirdafrist , 2008, Kearifan Lokal sekolah terhadap Tradisi Bangsa, 13 Februari 2008

Ansory, Nasruddin. 2008. Kearifan Lingkungan dalam Perspektif Budaya Jawa. Jakarta: Yayasan Obor.

Dahana, Radhar Panca. 2012. Generasi Digital. Kompas. Edisi Minggu, 28 November.

Dewan Kebudayaan. 2004. Golong-Gilig Manunggaling Kawula-Gusti dalam Pembangunan Berkelanjutan Daerah Istimewa Yogyakarta.

Dinas Kebudayaan Provinsi DIY. 2007. Penyusunan Kebijakan tentang Kebudayaan Lokal dan Daerah melalui Penyusunan Kajian Tata Nilai Budaya Daerah Yogyakarta. Yogyakarta: Dinas Kebudayaan.

Geertz, Clifford. 1973. The Interpretation of Cultures. New York: Basic Books, Inc., Publishers.

Idi, Abdullah. 2013. Pengembangan Kurikulum Teori dan Praktik. Jakarta: Raja Grafindo Persada.

Koentjaraningarat. 1984. Kebudayaan, mentalitas, dan Pembangunan. Jakarta: PT. Gramedia.

Koentjaraningarat. 1987. Sejarah Teori Antropologi 1. Jakarta: UI Press.

Mardjono. 2004. Dengan Budaya Jawa Menggarap Dunia Bagi Terwujudnya Indonesia yang Besar dan Jaya. Makalah disampaikan dalam Dialog Kebudayaan Nasional Kerjasama Pusat Studi Budaya dan Puslit PKLH di Lembaga Penelitian UNY tanggal 8 desember 2004.

Marwito, Tirun. 2004. Kebudayaan Yogya dan Perspektifnya. Makalah disampaikan dalam Dialog Kebudayaan Nasional Kerjasama Pusat Studi Budaya dan Puslit PKLH di Lembaga Penelitian UNY tanggal 8 Desember 2004.
Naufel, Ahmad dkk. 2014. Pancasila, Budaya Virtual dan Globalisasi. Purwokerto: STAIN Press.

Padmanugraha, A.S. 2010. Common Sense Outlook on Local Wisdom and Identity: A Contemporary Javanese Natives Experience. Paper Presented in International Conference on Local Wisdom for Character Building, Yogyakarta.

Ridwan, Norma. 2007. Landasan Keilmuan Kearifan Lokal. Makalah dalam Jurnal Studi Islam dan Budaya Ibda'.Vol. 5. No. 1. JanJun 2007. Hlm. 27-38.

Rif'an, Ali dkk.. 2012. Indonesia Hari Esok. Purwokerto: STAIN Press.

Soenarto. 2004. Kebudayaan Jawa dan Perspektifnya. Makalah disampaikan dalam Dialog Kebudayaan Nasional Kerjasama Pusat Studi Budaya dan Puslit PKLH di Lembaga Penelitian UNY tanggal 8 Desember 2004.

Suastra, I. Wayan. 2010. Model pembelajaran sains berbasis budaya lokal untuk mengembangkan kompetensi dasar sains dan nilai kearifan lokal di SMP. Jurnal Pendidikan dan Pengajaran 43.2 p. 8-16.

Suminto, A. 2005, Menuju Situasi Sadar Budaya: Antara "Yang Lain" dan kearifan Lokal, Lembaga Pendidikan Semi Palar, 24 Februari 2005 Mukhlason,akhmad, 2000, Membangun Pendidikan Memasuki Millenium Baru, 16 Februari 2000.

Sutarno. 2008. Pendidikan Multikultural. Jakarta: Direktorat Jenderal Pendidikan Tinggi, Depdiknas.

Suwito, Yuwono Sri. 2008. Pendidikan Berbasis Budaya Yogyakarta. Makalah, Disampaikan dalam Sarasehan Budaya Selasa Wagen di Bangsal Kepatihan, 15 Juli 2008.

Wagiran, dkk. 2010. Pengembangan Model Pendidikan Kearifan Lokal di Wilayah Provinsi DIY dalam Mendukung Perwujudan Visi Pembangunan DIY menuju Tahun 2025(Tahun Kedua). Penelitian. Yogyakarta: Biro Administrasi Pembangunan. 